http://dx.doi.org/10.12775/szhf.2013.021

\title{
Śmierć jako źródło i przedmiot prawa. Stanowisko Thomasa Hobbesa
}

\section{Część II: Śmierć jako przedmiot prawa}

1. Zakaz zabijania. Zakaz zabijania wynika bezpośrednio z prawa do życia, zabójstwo bowiem to zło absolutne, pozbawiające wszelkich dóbr ${ }^{1}$. Jest także złamaniem umowy, której należy dotrzymać nie tylko z szacunku dla prawa czy wierności wobec zobowiązań, lecz także z racji własnego interesu; łamiąc umowę, narażam się na podobne traktowanie ze strony innych ${ }^{2}$. Zabójstwo jest więc nie tylko złem dla ofiary, lecz także dla agresora, który staje się potencjalną ofiarą; $\mathrm{z}$ tego powodu łamanie umowy Hobbes nazywa szaleństwem ${ }^{3}$, jej dotrzymanie zaś - środkiem do przetrwania.

Prawny zakaz zabijania dotyczy czynów, nie zaś skrytych myśli; znaczy to, że myślenie o czyjejś śmierci z przyjemnością (lub dostrzeganie w niej własnego pożytku) nie jest przestępstwem, o ile nie skutkuje podjęciem dzia-

${ }^{1}$ T. Hobbes, Lewiatan, czyli materia, forma i władza państwa kościelnego i świeckiego, tłum. Cz. Znamierowski, Warszawa 2009, s. 396. Z tego powodu zakaz ten nie wymaga dodatkowych uzasadnień. Zła zabójstwa mógłby nie dostrzec tylko ten, kto chciałby zostać zabity przez innego; takich jednak ludzi, zdaniem Hobbesa, nie ma.

2 Tamże, s. 226, 230-231.

3 Tamże, s. 230. Zdaniem Hobbesa szaleństwem jest ono także w przypadku człowieka wierzącego w życie wieczne i eschatologiczne sankcje moralne; nikt bowiem nie może racjonalnie ufać, że dostąpi szczęścia wiecznego, jeśli będzie łamał umowy. Tamże. 
łań, mogących zagrażać życiu danej osoby ${ }^{4}$. Także życzenie komuś śmierci nie jest przestępstwem, chociaż może być uznane za grzech ${ }^{5}$; prawo jednak interesuje się dopiero faktycznym zabójstwem lub jawnie wypowiadanymi groźbami śmierci, nie zaś myślami. Nawet grzechem jednak nie jest natrętna myśl, wyrażająca życzenie śmierci, jeśli nachodzi nas wbrew woli; nikt bowiem, zdaniem Hobbesa, nie może być odpowiedzialny za myśli, na które nie ma wpływu'6.

Pomimo powszechnego zakazu zabijania, ocena zabójstwa zależy od jego okoliczności. Większym złem jest zabójstwo poprzedzone groźbami śmierci niż nagłe i potajemne; podobnie większym złem jest zabić kogoś, torturując go, niż spowodować jego śmierć natychmiast oraz zabić rodzica niż osobę obcą, rodzic bowiem dał życie i powinien być czczony jak suweren ${ }^{7}$. Podając te przykłady, Hobbes polemizował z tezą starożytnych stoików, zgodnie z którą wszystkie przestępstwa są złem jednakowym. Zdaniem Hobbesa pogląd ten jest nie do przyjęcia, w oczywisty bowiem sposób zabicie ojca jest gorsze od zabicia kury ${ }^{8}$.

Szczególną postacią zabójstwa jest zabójstwo w pojedynku, co w czasach Hobbesa było istotnym problemem. Wprawdzie prawo brytyjskie uznawało prywatne pojedynki za nielegalne, dopuszczało jednak pojedynek sądowy, oskarżony miał bowiem prawo pozwać swego oskarżyciela; przepis ten uchylono dopiero w 1819 roku9 . Zdaniem Hobbesa pojedynki są wprawdzie świadectwem odwagi, stanowią jednak również skutek błędnej umowy i fałszywego pojmowania honoru ${ }^{10} ; \mathrm{z}$ tego powodu powinny być zakazane. Zarazem jednak Hobbes dowodził, że nie można człowieka pozbawić prawa do obrony, co oznacza także prawo do zabicia agresora (przynajmniej w sytuacji, w której wszelkie instytucjonalne środki zawiodły $)^{11}$. Problem w tym, że pojedynek nie oznacza obrony koniecznej, lecz zgodę na rozstrzygnięcie spornej sprawy przez śmierć. W takim zaś razie zabójstwo w pojedynku jest

4 Tamże, s. 376.

${ }^{5}$ Życzenie śmierci należy odróżnić jeszcze od zamiaru zabójstwa; ten ostatni jest dla Hobbesa grzechem, nawet, jeżeli nigdy nie został zrealizowany. Tamże, s. 377.

6 Tamże.

7 Tamże, s. 394-395.

8 Tamże, s. 386. Pomijamy kwestię, czy zaproponowana przez Hobbesa interpretacja poglądu stoików jest słuszna.

${ }^{9} \mathrm{~W}$ Anglii ostatni taki pojedynek odbył się w roku 1638. B. Szyndler, Pojedynki, Warszawa 1987, s. 20.

${ }^{10}$ T. Hobbes, Lewiatan, s. 174.

${ }^{11}$ Tamże, s. 381, 384-385. 
przestępstwem, świadczy bowiem o tym, że człowiek nie wykorzystał innych środków obrony.

$\mathrm{Na}$ gruncie teorii Hobbesa zabicie agresora jest dopuszczalne jedynie w obronie własnego (a nie cudzego) życia; najpierw bowiem mamy obowiązek dbać o własny interes a dopiero na drugim miejscu o interes bliskich. Wbrew temu jednak są sytuacje, kiedy mam nie tylko prawo, lecz także obowiązek zabić agresora, który morduje osobę, za którą jestem odpowiedzialny (np. moje dziecko). Hobbes takiego przypadku nie rozważał, akcentując prawa jednostki i jej obowiązki względem siebie; obowiązki wobec drugich zrzucał na suwerena. Znaczy to, że prawo (obowiązek) zabicia osoby zagrażającej życiu innych jest wyłącznie prawem (obowiązkiem) władcy, nie zaś obywateli. Zasada ta w sposób naturalny sugeruje konieczność ustanowienia przez władcę kary śmierci.

2. Kara śmierci. W stanie natury nie ma sensu mówić o karze, nie ma bowiem przestępstw; obowiązuje jedynie prawo do obrony własnego życia wszelkimi środkami. W państwie prawo do zabójstwa prewencyjnego zostaje zniesione, pojawia się jednak kwestia stosowalności kary śmierci przez władzę. Na gruncie teorii Hobbesa problem ten rodzi istotny dylemat, kara śmierci bowiem powinna być zarazem wykluczona (z racji prawa do życia) i dopuszczona bez ograniczeń (z racji pozycji suwerena).

Na pierwszy rzut oka zakaz kary śmierci wydaje się oczywisty, ponieważ jej stosowanie stanowi jawny przykład pogwałcenia prawa do życia. Co więcej, jej legalizacja wydaje się kłócić z celami umowy i funkcjami państwa, suweren bowiem został powołany po to, by chronić życie obywateli. Jeśli jednak obowiązuje kara śmierci, to każdy może zostać na nią skazany; system okazuje się zatem niespójny - zawiera niezbywalne prawo do życia, dopuszczając zarazem zabicie obywatela na mocy legalnego wyroku ${ }^{12}$. W ten sposób prawo, które ma chronić obywateli, stanowi dla nich zagrożenie; zamiast zaś ograniczać lęk przed śmiercią, może go dodatkowo potęgować, nikt bowiem nie ma gwarancji, że nie popełni przestępstwa ani nie zostanie fałszywie oskarżony.

$\mathrm{Z}$ drugiej strony na gruncie teorii Hobbesa nie widać żadnych podstaw do ograniczeń stosowania kary śmierci. Skoro bowiem suweren jest ponad umową, wszyscy inni zaś jego poddanymi, to wolno mu stosować dowolne kary; mógłby nawet skazywać na śmierć osoby niewinne, co ilustruje przykład

\footnotetext{
${ }^{12}$ Na niespójność między umową społeczną a karą śmierci wskazywał najbardziej znany nowożytny krytyk kary śmierci Cesare Beccaria. P. Bartula, Kara śmierci. Powracający dylemat, Kraków 2007, s. 113.
} 
biblijny, przywołany przez Hobbesa. Wódz Izraela, Jefte, obiecał Bogu, że jeśli zwycięży w bitwie - złoży w ofierze pierwszą żywą istotę, którą spotka po powrocie do domu; i chociaż okazała się nią jego ukochana córka, słowa dotrzymał. Według Hobbesa jednak, Jeftego nie tyle obowiązywała obietnica dana Jahwe, ile - jako suwerenny władca - miał prawo skazać na śmierć osobę niewinną ${ }^{13}$.

Niezależnie od powagi zarysowanego dylematu, jego rozwiązanie wydaje się możliwe; w tym celu należy rozważyć szczegółowe racje przytaczane przez Hobbesa na rzecz kary śmierci. Pierwszy argument miał charakter historyczny, przywołując jej stosowanie w Izraelu z rozkazu Jahwe; wykonywano ją za bałwochwalstwo, morderstwo i inne przestępstwa ${ }^{14}$. Argument ten jednak nie wystarcza do prawnego usankcjonowania kary śmierci; stąd bowiem, że stosowano ją w imię Boga, nie wynika jej słuszność.

Drugi argument wiąże się z bezpieczeństwem społecznym, zdaniem Hobbesa bowiem najsurowsze kary należy nakładać za przestępstwa najbardziej niebezpieczne dla ogółu, zwłaszcza za złamanie umowy ${ }^{15}$. Kara śmierci stanowi zatem konsekwencję kontraktu; skoro bowiem wszyscy mają obowiązek dążyć do pokoju jako najskuteczniejszego środka ochrony życia, to każdy, kto niszczy pokój, winien zostać ukarany śmiercią. Burzycielem pokoju jest ten, kto chciałby usunąć suwerena lub nastaje na życie innych obywateli; w takich wypadkach kara śmierci jest nie tylko dopuszczalna, lecz także konieczna, jeśli bowiem władca będzie tolerować wrogów pokoju, to nie wypełni swego zadania ${ }^{16}$. $\mathrm{Z}$ drugiej strony, zbrodniarz nie może żądać, aby wobec niego przestrzegano zasad umowy, zwłaszcza, że działał w sposób wolny ${ }^{17}$. W od-

${ }^{13}$ Tamże, s. 299-300. Hobbes deklaruje zatem, że władca ma prawo zabić niewinnego. Wzorem jest tu relacja Boga do świata; Bóg ma bowiem prawo dowolnie karać ludzi nie dlatego, że ich stworzył, lecz dlatego, że dysponuje mocą, której nikt nie może się przeciwstawić. Tamże, s. $300,441-442$.

${ }^{14}$ Tamże, s. 791-792. „W tej sprawie panuje w świecie biblistów i historyków powszechna zgoda, że w całej historii zbawienia przed Chrystusem, kara śmierci funkcjonowała w kodeksie karnym Izraela jako sankcja uznana bezspornie za moralnie dopuszczalną, ponadto stosowana za przestępstwa różnego rodzaju”. T. Ślipko, Kara śmierci z teologicznego i filozoficznego punktu widzenia, Kraków 2002, s. 17.

${ }_{15}$ T. Hobbes, Lewiatan, s. 433. Niewątpliwie kara śmierci jest karą główną, chociaż można ją stosować w różny sposób, na przykład łącząc z torturami. Tamże, s. 400.

${ }^{16}$ Zdaniem Hobbesa na karę śmierci zasługuje również szpieg, dążący do zniszczenia państwa. Tamże, s. 788-789.

17 Tamże, s. 299-300. 
niesieniu do niego jej zerwanie wydaje się zatem uzasadnione ${ }^{18}$, kara śmierci bowiem to nie zemsta, lecz usprawiedliwiona obrona.

Argument ten nie jest jednak przekonujący; skoro bowiem prawo do życia jest niezbywalne, to nikomu nie można go odebrać. Kłopotliwe jest także odwołanie się do wolności zbrodniarza, na gruncie teorii Hobbesa bowiem wolność to jedynie brak przeszkód w realizacji woli ${ }^{19}$. Żaden człowiek jednak (podobnie jak zwierzęta) nie ma wolności chcenia lub niechcenia; mamy tylko wolność wykonania lub niewykonania swych zamierzeńn ${ }^{20}$. Zdaniem Hobbesa pozwala to jednak uznać nasze czyny za wolne, zwłaszcza, że każdy potrafi powstrzymać się od przestępstw z lęku przed prawem i represjami państwa ${ }^{21}$. Znaczy to, że groźba kary śmierci mogłaby powstrzymać niektórych od popełnienia zbrodni, stanowiąc istotny środek prewencji.

Argument ten jest o tyle istotny, że jeśli suweren ma chronić obywateli, to musi mieć skuteczne narzędzia sprawowania władzy ${ }^{22}$, wśród nich karę śmierci. Z jednej wszak strony władza musi sprawiedliwie karać zbrodnie już popełnione, $\mathrm{z}$ drugiej - zapobiegać kolejnym. Zdaniem Hobbesa tymczasem każdy ma prawo złamać umowę w sytuacji, gdy ma uzasadnione podejrzenie (reasonable suspicion), że drugi ją złamał23. Jeśli zaś prawo to ma obywatel, to tym bardziej musi je mieć suweren. Przykładem byli dla Hobbesa starożytni Ateńczycy, których nie interesowało przestępstwo popełnione przez skazanych, lecz to, jaką szkodę mogliby wyrządzić ${ }^{24}$. Sugeruje to zgodę na ukaranie śmiercią $\mathrm{w}$ celach prewencyjnych każdego, o kim suweren miałby podejrzenie, że jest niebezpieczny. Kara śmierci powinna zatem być zalegalizowana, zwłaszcza, że samo jej istnienie może ilość zbrodni ograniczać. Skoro zaś suweren jest ponad umową, to obywatele nie mogą oceniać słuszności

\footnotetext{
${ }^{18}$ S. J. Finn, Hobbes. A Guide for the Perplexed, London - New York 2007, s. 91.

19 T. Hobbes, Lewiatan, s. 295-296.

${ }^{20}$ F. C. Copleston, Historia filozofii, t. 5: Od Hobbesa do Hume’a, tłum. J. Pasek, P. Józefowicz, Warszawa 2005, s. 30, 32.

${ }^{21}$ T. Hobbes, Lewiatan, s. 297.

${ }^{22}$ S. J. Finn, Hobbes, s. 91.

${ }^{23}$ Tamże.

${ }^{24}$ T. Hobbes, Lewiatan, s. 300. Była to podstawowa zasada, którą Hobbes postulował w odniesieniu do wszelkiego typu kar (a nawet do zemsty); zasadniczym punktem odniesienia powinno być nie minione zło, które już się stało, lecz ewentualne przyszłe dobro, które można uzyskać. J. Hołówka, Etyka w działaniu, Warszawa 2001, s. 337.
} 
prawa, które im narzucił; mógłby nawet ustanowić złe prawo, jest to bowiem lepsze, niż brak prawa i stan wojny ${ }^{25}$.

Argument ten jest jednak kłopotliwy, nie wiadomo bowiem, na czym polega racjonalne podejrzenie, że ktoś złamał umowę. Zewnętrzne oznaki mogące to sugerować nie są dowodem wystarczającym, władca zaś nie może polegać jedynie na swoich przeczuciach czy lękach. Co więcej, stosowanie kary śmierci zdradza słabość państwa, które nie potrafi bronić obywateli inaczej, jak tylko skazując niektórych na śmierć ${ }^{26}$. Skoro bowiem w państwie zdarzają się zbrodnie, świadczy to, że suweren nie wypełnia należycie swych zadań.

Na tak sformułowany zarzut można odpowiedzieć, że całkowita eliminacja przestępstw nie jest możliwa; nawet suweren jest bezradny w sytuacji skrytobójstwa czy zbrodni w domu rodzinnym ${ }^{27}$. Warunkiem zapobiegania im musiałoby być państwo policyjne, kontrolujące każde nasze działanie. Jeśli chcemy go uniknąć, to jedyną ochroną obywateli może być prawo minimalizujące ryzyko zła; skoro zaś kara śmierci może zapobiegać przestępstwom, to należy ją dopuścić. Nie jest ona jednak zbrodnią, lecz sprawiedliwym aktem państwa, stanowiącym karę za konkretny czyn ${ }^{28}$.

Nawet zgadzając się z tą argumentacją, należy zauważyć, że według Hobbesa kara nie ma być zemstą, lecz służyć poprawie przestępcy ${ }^{29}$; wówczas jednak kara śmierci powinna być wykluczona, uniemożliwia bowiem przemianę zbrodniarza. Funkcję tę mogłaby pełnić tylko pod warunkiem istnienia życia wiecznego; skrócenie życia na ziemi byłoby wtedy ekspiacją za zło. Jeśli jednak pominąć perspektywę eschatologiczną, to kara śmierci żadnej przemianie przestępcy nie służy ${ }^{30}$.

${ }^{25}$ J. Rawls, Wykłady z historii filozofii polityki, oprac. S. Freeman, przeł. S. Szymański, Warszawa 2010 , s. $141,143$.

${ }^{26}$ Argument ze słabości państwa wytaczał przeciwko karze śmierci wspomniany wcześniej Beccaria. M. Ossowska, Normy moralne. Próba systematyzacji, Warszawa 1985, s. 43. Podobnie argumentował J. J. Rousseau; wprawdzie dopuszczał karę śmierci, uważał jednak, że częste egzekucje dowodzą słabości i opieszałości władzy. J. J. Rousseau, Umowa społeczna, przeł. A. Peretiatkowicz, [w:] J. J. Rousseau, Umowa społeczna. List o widowiskach, Warszawa 2010, s. 41.

${ }^{27}$ Suweren nic przecież nie może poradzić, gdy mąż zaplanuje zabójstwo niczego nie podejrzewającej żony w łożu małżeńskim, pod osłoną nocy.

${ }^{28}$ T. Hobbes, Lewiatan, s. 331.

29 Tamże, s. 433.

${ }^{30}$ Można argumentować, że sama już świadomość zasądzonego wyroku śmierci i nieuchronność jego wykonania zmienia przestępcę, dając mu czas na refleksję nad złem, którego się dopuścił; oczekiwanie na wykonanie wyroku można byłoby zatem uznać za czas moralnej przemiany. Wtedy jednak pojawia się problem, czy - jeśli taka przemiana przestępcy rzeczywiście 
Niezależnie od funkcji kary śmierci, Hobbes sądził, że nie przeczy ona prawu do życia. System ją dopuszczający jest spójny, ponieważ każdy, także burzyciel pokoju, ma prawo do obrony życia ${ }^{31}$. Może on fałszywie zeznawać w sądzie lub nawet walczyć zbrojnie ${ }^{32}$, złamanie umowy nie pozbawia go bowiem praw przez nią gwarantowanych. Istnieje zatem różnica między teorią Hobbesa i Rousseau, według którego zbrodniarz łamiący umowę sam wyklucza się ze społeczeństwa ${ }^{33}$. Zdaniem Hobbesa tymczasem nawet przestępca skazany na śmierć ma prawo walczyć o uniknięcie wyroku ${ }^{34}$. Skoro zaś kara śmierci nie przeczy prawu do życia, to może zostać zalegalizowana. Uzasadnia ją prewencja (groźba śmierci powstrzymuje od przestępstw) ${ }^{35}$, cele pań-

się dokonała - należy wykonać egzekucję; skazany jest już wszak innym człowiekiem, a zatem wydany na niego wyrok śmierci spełnił cele moralne i wychowawcze. Jeśli jednak przemianie przestępcy służy nie zadanie śmierci, lecz jej zasądzenie, bez ostatecznego wykonania wyroku, to powstaje kolejny paradoks: kara śmierci, która jest tylko zasądzana, lecz nigdy nie wykonywana, okazuje się fikcją, potencjalny zbrodniarz będzie ją zatem lekceważyć.

${ }^{31}$ Tamże, s. 306.

${ }^{32}$ Tamże, s. 304, 306.

${ }^{33}$ J. J. Rousseau, Umowa społeczna, s. 40. Podobnie uzasadniał karę śmierci Tomasz z Akwinu; jego zdaniem możną ją zastosować wobec tego, kto - popełniając najcięższą zbrodnię - pozbawił się w ten sposób ludzkiej godności. K. Renda, Kontrowersje w etyce kary śmierci, [w:] A. Mazurek (red.), Kara śmierci. Historia. Prawo. Etyka, Lublin 2006, s. 29. Sugeruje to, że godność osobowa w ujęciu Tomasza nie jest cechą ontyczną i niezbywalną, lecz moralną i możliwą do utracenia.

${ }^{34}$ T. Hobbes, Lewiatan, s. 223. Tym bardziej nie może istnieć żaden przymus, by skazany na śmierć sam na sobie wykonał wyrok. Tamże, s. 304. Hobbes nie uznałby zatem czynu Sokratesa za słuszny ani sprawiedliwy; za racjonalną uznałby raczej ucieczkę Sokratesa z więzienia. Podobnie zapewne oceniłby czyn Seneki, który popełnił samobójstwo na rozkaz Nerona.

${ }_{35}$ Ten argument był często stosowany prze krytyków kary śmierci, trudno jednak ocenić jego słuszność, ponieważ rozstrzygające badania musiałyby być niezwykle skrupulatne, uwzględniając wiele czynników, często trudnych do uchwycenia, takich jak motywacje przestępców, świadomość grożących im kar w trakcie planowania lub popełniania zbrodni, zależność liczby i rodzaju przestępstw od środowiska społecznego itd. Niektóre z dostępnych statystyk zdają się wskazywać na istnienie zależności między liczbą wykonanych wyroków śmierci a liczbą zabójstw; ta ostatnia jest mniejsza, jeśli za zabójstwo grozi kara śmierci. Szacuje się, na przykład, że w Stanach Zjednoczonych, w latach 1933-1967, wykonane wyroki śmierci uratowały rocznie życie 7-8 osób. J. Hołówka, Etyka $w$ działaniu, s. 341. W książce tej zreferowane zostały również argumenty podważające wiarygodność przytoczonych statystyk. Tamże, s. 341-343. Argument, że kara śmierci odstrasza potencjalnych zbrodniarzy, był podważany przez Alberta Camusa. Pisarz przytoczył dane, że w roku 1886 skazano na śmierć 167 osób z więzienia w Bristolu; 164 spośród nich było wcześniej przynajmniej raz świadkiem egzekucji. A. Camus, Rozważania o gilotynie, tłum. W. Szydłowska, [w:] W. Szydłowska, Camus, Warszawa 2002, s. 174. 
stwa (żaden suweren nie może tolerować morderców) oraz prawo przestępcy do obrony (nikt nie zobowiązuje się dobrowolnie poddać karze) ${ }^{36}$.

3. Samobójstwo. Z perspektywy dążenia do zachowania własnego życia istotnym problemem okazuje się samobójstwo. Pierwsze pytanie dotyczy samej jego możliwości, wszelkie bowiem działanie mające na celu skrócenie własnego życia, wydaje się przeczyć instynktowi przetrwania. Drugi problem wiąże się z moralną dopuszczalnością czynu samobójczego.

Jeśli chodzi o kwestię pierwszą, to mogłoby się wydawać, że fakt samobójstw dowodzi ich możliwości. W rzeczywistości jednak czyn ten sprzeciwia się dążeniu do zachowania siebie, trudno go zatem uznać za celowy i świadomie zaplanowany ${ }^{37}$. Zwykle jest wymuszony szantażem lub nieznośnym cierpieniem; wtedy jednak oznacza nie skrócenie życia, lecz bólu, nie przecząc instynktowi samozachowawczemu ${ }^{38}$.

Jeśli chodzi o problem drugi, to przytacza się zwykle dwa argumenty przeciw dopuszczalności samobójstwa. Pierwszy, sięgający Platona i pisarzy chrześcijańskich, ma charakter teologiczny, uznając samobójstwo za grzech przeciwko Bogu, który dał nam życie dla określonego celu i tylko On ma prawo je zabrać ${ }^{39}$. Drugi argument ma charakter społeczny, odwołując się do powinności wobec innych ludzi. Głosi on, że odbierając sobie życie, zrywam umowę, zobowiązującą mnie do działania dla dobra innych, wobec czego samobójstwo należy uznać za przestępstwo podlegające karze ${ }^{40}$.

\footnotetext{
${ }^{36}$ „[... nikt nie zobowiązuje się do dobrowolnego poddania się karze i nie zrzeka się prawa do ucieczki. Umowa zawierająca zobowiązania niemożliwe byłaby nieważna. Do umowy społecznej przystępują ludzie jako istoty dążące ze strachu przed nagłą śmiercią do przezwyciężenia stanu natury, ale w stanie państwowym nadal mają prawo uciekać i walczyć o życie wszelkimi sposobami. Nie ma więc sprzeczności pomiędzy umową społeczną a karą śmierci”. P. Bartula, Kara śmierci, s. 118.

${ }^{37}$ J. Rawls, Wykłady z historii filozofii polityki, s. 99.

${ }^{38}$ Podobnie argumentował Spinoza, zdaniem którego samobójstwo jest niemożliwe, nie istnieje bowiem żadne ja, które zabija siebie; w takim przypadku mamy raczej do czynienia z sytuacją rozdwojenia jaźni - jedno ja zabija inne ja, którego nie akceptuje. Wyraża to chociażby twierdzenie 4 części III Etyki, głoszące, że „wszelka rzecz zniszczona być może jedynie przez przyczynę zewnętrzną". B. Spinoza, Etyka, przeł. I. Halpern-Myślicki, Kęty 2000, s. 544. Niemożliwość samobójstwa wiąże się z ideą, iż treścią istotną każdej rzeczy jest dążenie do zachowania siebie.

${ }^{39}$ Argument ten był popularny także w nowożytności; przywoływali go m.in. Hugo Grotius i John Locke. Jego krytykę przeprowadził David Hume w znanym eseju O samobójstwie.

${ }^{40}$ Przykładem stosowania takiej argumentacji było wiele systemów prawnych w Europie. We Francji karano próby samobójcze śmiercią, w Anglii zaś przepadkiem mienia; jeśli próba sa-
} 
Na gruncie teorii Hobbesa obydwa argumenty tracą moc; jeśli bowiem nawet stworzył nas Bóg, to stąd nie wynika, że mamy obowiązek dla Niego żyć ${ }^{41}$. Nasze obowiązki są raczej skutkiem Jego mocy niż aktu kreacji, Bóg zaś nie zakazał samobójstwa. Upada także argument społeczny, według Hobbesa bowiem człowiek ma przede wszystkim obowiązki wobec siebie, dopiero wtórnie zaś wobec innych; nie mamy zatem obowiązku żyć dla innych ${ }^{42}$.

Nie znaczy to, że każdy i w każdych warunkach ma prawo odebrać sobie życie. $\mathrm{Z}$ pewnością niedopuszczalne jest samobójstwo suwerena, grozi ono bowiem przywróceniem stanu natury; źródłem zła nie jest jednak sam czyn, lecz jego konsekwencje dla obywateli. Podobnie niedopuszczalne jest samobójstwo skutkujące nieuchronnie śmiercią innej osoby. Także w tym przypadku źródłem zakazu nie jest odebranie sobie życia, lecz fakt, że czyn ten oznacza zarazem śmierć innej osoby. Sugeruje to, że gdyby samobójstwo nie miało negatywnych konsekwencji dla innych (nade wszystko zaś - gdyby nie prowadziło do śmierci innej osoby), byłoby dopuszczalne.

Jest oczywiste, że teoria Hobbesa wyklucza możliwość nakazu samobójstwa; nawet zatem, jeśli suweren go wyda, nikt nie ma obowiązku go spełnićs ${ }^{43}$. Mimo to decyzja o samobójstwie może być racjonalna, jeśli chroni człowieka przed większym złem. Gdyby bowiem ktoś mnie szantażował, że - jeśli nie odbiorę sobie życia - będzie mnie przez wiele lat torturować, ja zaś nie miałbym możliwości uniknięcia groźby, to wówczas mógłbym mieć powód do zadania sobie śmierci; nie byłoby to jednak samobójstwo dobrowolne, lecz wymuszone okolicznościami.

Jeśli życie jest dobrem najwyższym, a śmierć absolutnym złem, to nie tylko nie wolno nikogo do samobójstwa skłaniać, lecz należy czynić wszystko, aby potencjalnych samobójców od ich zamiaru odwieść. W tej sytuacji - na gruncie teorii Hobbesa - mogłoby się wydać słuszne ustanowienie zakazu samobójstw; skoro bowiem suweren ma bronić obywateli, to jego obowiązkiem jest ratować ich życie także wtedy, gdy sami usiłują je sobie odebrać. Poza tym, na gruncie metafizycznego egoizmu, samobójstwo jest większym złem niż

mobójcza zakończyła się śmiercią, to rodzina zmarłego traciła prawo do spadku. M. Ossowska, Normy moralne, s. 35.

${ }^{41}$ J. Rawls, Wykłady z historii filozofii polityki, s. 95.

42 Szczegółowo argument ten rozwinął Hume w przywołanym wyżej eseju O samobójstwie, nie nawiązując jednak bezpośrednio do Hobbesa. Argumentację Hume’a omówiłem w artykule Prawo do samobójstwa - stanowisko Davida Hume’a, złożonym do druku w „Przeglądzie Filozoficznym".

${ }^{43}$ S. J. Finn, Hobbes, s. 102. 
zabójstwo, zabójca wszak nadal zachowuje swe życie, samobójca zaś bezpowrotnie je traci. W takim razie zakaz samobójstwa należy uznać za racjonalny i zgodny z prawem natury, które wskazuje, co należy czynić i czego unikać, aby zachować swe życie ${ }^{44}$. Problem w tym, że zakaz samobójstwa sugerowałby, iż mamy bezwzględny obowiązek żyć. Niektórzy komentatorzy uważają, że jest to zgodne z poglądem Hobbesa, w myśl którego człowiek ma przede wszystkim zobowiązania wobec siebie ${ }^{45}$. Taka interpretacja rodzi jednak inny problem, na który zwrócił uwagę Robert Filmer. Jeśli bowiem w stanie natury człowiek może czynić wszystko, co uważa za słuszne dla zachowania siebie, to natura musiała go pouczyć, co służy jego przetrwaniu, chroniąc go zarazem przed czynieniem tego, co mu zagraża. Ponieważ zaś Hobbes przeczył, że człowiek ma wolność zniszczenia własnego życia, Filmer sugerował, iż zakaz samobójstwa jest zbędny (skoro chroni nas instynkt życia) lub nieskuteczny (skoro możemy się temu instynktowi skutecznie przeciwstawić) ${ }^{46}$.

Można też argumentować, że zachowanie życia jest naszym podstawowym uprawnieniem, nie jest jednak imperatywem ${ }^{47}$; wprawdzie każdy musi respektować cudze prawo do życia, jednak nikt nie ma obowiązku zachowania siebie. Samobójstwo nie łamie zatem umowy ${ }^{48}$, chociaż wydaje się nieracjonalne i niezgodne $z$ własnym interesem. Mimo to Hobbes dopuszczał, że życie może być złem jako nieznośne cierpienie, śmierć zaś dobrem jako jego kres. Sytuacja taka jest jednak wyjątkowa, co ilustruje przykład podany w De Cive, ukazujący los syna, któremu suweren nakazał zabić rodzica ${ }^{49}$.

${ }^{44}$ J. Rawls, Wykłady z historii filozofii polityki, s. 75. Prawa natury wprost zakazują nam czynić to, co byłoby dla naszego życia niszczące lub co odbiera nam środki do jego zachowania. Tamże, s. 75-76. Samobójca działa zatem wbrew prawu natury. A. P. Martinich, Hobbes, New York-London 2005, s. 241, p. 11.

${ }^{45}$ „Samobójstwo jest, według Hobbesa, przeciwieństwem naturalnej tendencji występującej w przyrodzie. Dążenie do samozachowania jest bowiem najważniejszym zobowiązaniem człowieka występującym pod postacią prawa natury. Każdy człowiek, powiada Hobbes, powinien zawsze podejmować 'największy możliwy wysiłek' w celu realizacji tego zobowiązania”. S. Kijaczko, Wobec bycia. Filozoficzny problem samobójstwa, Wydawnictwo Uniwersytetu Opolskiego, Opole 2005, s. 132.

${ }^{46}$ R. Tuck, Hobbes: A Very Short Introduction, Oxford University Press 1989, s. 73.

${ }^{47}$ S. Kijaczko, Wobec bycia, s. 134.

${ }^{48}$ A. P. Martinich, Hobbes, s. 241, p. 11. W umowie deklaruję jedynie, że nie będę zabijał innych, nie zobowiązuję się jednak, że sam sobie życia nigdy nie odbiorę. W koncepcji Locke’a umowa społeczna była rozumiana szerzej, wymuszając na jednostce zobowiązanie życia i działania dla dobra innych.

${ }^{49}$ T. Hobbes, On the Citizen, edited and translated by R. Tuck, M. Silverstone, Cambridge University Press 1998, s. 83; R. Tuck, Hobbes, 102. 
Jeśli nie spełni rozkazu, sprzeciwi się władzy i narazi na niebezpieczeństwo; jeśli spełni rozkaz, popełni ewidentne zło, nie godzi się bowiem nastawać na życie rodziców. W takiej sytuacji człowiek może chcieć raczej umrzeć, niż zabić rodzica ${ }^{50}$. Zdaniem Finna przykład ten może wskazywać na niespójność teorii Hobbesa, z jednej strony uznającej śmierć za największe zło, którego każdy chce uniknąć, z drugiej dopuszczającej możliwość pragnienia śmier$\mathrm{ci}^{51}$. Wydaje się jednak, że tezy te nie są niespójne, syn bowiem nie tyle chce umrzeć, ile wybiera śmierć ze względu na okoliczności; wybrać śmierć zaś nie jest tym samym, co pragnąć jej ${ }^{52}$. Gdyby zatem nawet syn popełnił samobójstwo, nie przeczyłoby ono instynktowi życia. Wprawdzie kamień spada w dół, można go jednak również podrzucić do góry; podobnie instynkt skłania nas do obrony życia, okoliczności mogą go jednak osłabićs ${ }^{53}$. Nawet zatem, jeśli śmierć jest złem, to jednak w pewnych okolicznościach może się okazać złem mniejszym.

Samobójstwo może być także skutkiem silnego wzburzenia emocjonalnego ${ }^{54}$. Hobbes podał przykład starożytnego miasta, w którym pojawiły się masowe samobójstwa młodych dziewcząt. Większość ludzi uznawało je za opętane, niektórzy sądzili jednak, że powodem samobójstw są złe myśli i uczucia. Władcy postanowili wszystkie samobójczynie wieszać nago, co spowodowało kres samobójstw. Znaczy to, że ich powodem były złe emocje, silniejsze od instynktu przetrwania, źródłem ich zahamowania zaś okazał się szacunek dla siebie; nikt bowiem nie chce być przedmiotem publicznej hańby nawet po śmierci ${ }^{55}$.

Niezależnie jednak od motywacji samobójstwa należy stwierdzić, że - na gruncie teorii Hobbesa - stanowi ono krzywdę wyrządzoną samemu sobie; prawny jego zakaz jest zatem racjonalny. Mimo to są sytuacje, kiedy samobójstwo można usprawiedliwić jako mniejsze zło (chociażby unikając nieznośnego cierpienia czy tortur).

\footnotetext{
${ }^{50}$ J. Rawls, Wykłady z historii filozofii polityki, s. 99.

${ }^{51}$ S. J. Finn, Hobbes, s. 11, 55.

${ }^{52}$ Finn uważa, że tę niespójność można uznać za wynik zmiany poglądu przez Hobbesa lub nadinterpretacji słowa „każdy” w wyrażeniu „każdy pragnie żyć”; powinniśmy je bowiem odczytywać jako „niemal każdy”. Tamże, s. 11-12. Uznanie jednak, że nie wszyscy ludzie pragną żyć powoduje, że teoria Hobbesa traci powszechną ważność.

${ }^{53}$ J. Rawls, Wykłady z historii filozofii polityki, s. 99-100.

${ }^{54}$ Tamże, s. 99.

${ }^{55}$ T. Hobbes, Lewiatan, s. 156.
} 
4. Ofiara $\mathrm{z}$ życia. Jednym $\mathrm{z}$ istotnych problemów związanych ze śmiercią jest kwestia ofiary z siebie, wyrażająca się pytaniem, czy człowiek jest zdolny do poświęcenia własnego życia i czy wolno od niego takiej ofiary oczekiwać.

Z perspektywy metafizycznego egoizmu zdolność do ofiary z życia wydaje się wątpliwa; jeśli bowiem człowiek dąży przede wszystkim do zachowania siebie, to trudno pojąć poświęcenie własnego życia celem ratowania innej osoby. Zdaniem jednak niektórych komentatorów ofiara taka jest możliwa, człowiek ma bowiem również interesy transcendentne, związane z życiem wiecznym; może zatem ponieść śmierć, mając nadzieję na nagrodę (lub uniknięcie kary) w życiu przyszłym ${ }^{56}$. Argument ten jest jednak błędny, odwołuje się bowiem do przykładu realizacji własnego interesu (poświęcamy życie doczesne w imię wiecznego), ofiara tymczasem powinna być bezinteresowna.

Niezależnie od ludzkiej zdolności do ofiary, problemem jest jej racjonalność. Jeśli prowadzi ona do nagrody wiecznej, to z pewnością służy naszym interesom; jeśli jednak życie na ziemi jest jedyne, to wątpliwe, by istniała wartość godna jego utraty, każde bowiem dobro jest mniejsze od życia. Wówczas pojawia się problem obowiązku ofiary, wpisany w niektóre systemy etyczne, chociażby utylitaryzm, zgodnie z którym można (i należy) poświęcić jednostkę w imię dobra ludzkości. Nie chodzi tylko o ofiarę dobrowolną, lecz także o posłużenie się życiem osoby przez innych ${ }^{57}$. Sugeruje to, że także suweren miałby prawo (a nawet obowiązek) poświęcić życie jednego obywatela, celem ratowania pozostałych ${ }^{58}$.

Hobbes zdecydowanie jednak wykluczał taką instrumentalizację człowieka. Pomijając już kwestię, że ofiara wymuszona nie jest ofiarą, należy zauważyć, iż suweren nie może ustanowić żadnego nakazu niezgodnego z instynktem życia, ponieważ byłby on niemożliwy do wyegzekwowania. Nakaz ofiary jawnie przeczy też prawu do życia, które zezwala mi bronić siebie w każdych warunkach (nawet za cenę śmierci innych osób). Z kolei prawo do życia przysługujące innym nie pociąga za sobą obowiązku mojego poświęcenia dla ich ratowania, ma bowiem charakter minimalistyczny (zakaz zabijania), nie zaś maksymalistyczny (przymus ofiary). W umowie zobowiązujemy się, że nie

\footnotetext{
${ }^{56}$ Pogląd taki wyraża S. A. Lloyd w książce Ideals as Interests in Hobbes's „Leviathan” (Cambridge University Press, 1992). Cyt. za: A. P. Martinich, s. 232.

${ }^{57} \mathrm{Na}$ gruncie utylitaryzmu nie byłby to nawet akt heroizmu, wykraczający poza nasze obowiązki, lecz czyn stanowiący naszą naturalną powinność. Konsekwentny utylitaryzm dopuszcza także sytuację odwrotną, mianowicie poświęcenie grupy ludzi dla ratowania jednostki, jeżeli jej życie byłoby szczególnie ważne dla przyszłego rozwoju ludzkości.

${ }^{58}$ R. Tuck, Hobbes, s. 110.
} 
będziemy siebie wzajemnie mordować, nie zaś, że będziemy wzajemnie za siebie umierać. Stanowisko Hobbesa jest zatem indywidualizmem, przypisującym niezbywalne prawo do życia każdej jednostce, której wartość jest absolutna. W takim razie nie można ratować jednej kosztem innej, dobro wspólne bowiem to dobro wszystkich z osobna ${ }^{59}$.

Wniosek ten jest jednak kłopotliwy, kiedy bowiem nie można uratować wszystkich, teoria Hobbesa nie podpowiada, kogo ratować w pierwszej kolejności. Wydaje się, że sugeruje bądź to, że należy ratować przede wszystkim siebie $^{60}$, bądź, że należy ratować wszystkich. W pierwszym przypadku byłaby moralnym egoizmem, w drugim miałaby charakter utopijny, odnosząc się do sytuacji idealnej, kiedy możliwe byłoby ocalenie każdego. Jeśli jednak konieczny jest wybór, indywidualizm okazuje się bezradny; można jedynie domniemywać, iż (poza sobą) należy najpierw ratować władcę jako gwaranta bezpieczeństwa pozostałych osób. Z drugiej jednak strony, właśnie jako prawny obrońca poddanych, suweren wydaje się zobligowany do poświęcenia siebie celem ratowania życia poddanych.

Dodatkowym problemem jest to, że przynajmniej niekiedy powinniśmy poświęcić własne życie, ratując osoby, za które jesteśmy odpowiedzialni. Jeśli bowiem mam potomstwo, to w sytuacji zagrożenia mam obowiązek ratować raczej dzieci niż siebie, nawet za cenę własnej śmierci; teoria Hobbesa tymczasem sugerowałaby raczej ratowanie siebie niż własnych dzieci. Wydaje się, że jedynym rozwiązaniem wskazanego dylematu byłoby odróżnienie prawa do ofiary i obowiązku ofiary; wprawdzie umowa, która zmuszałaby kogokolwiek do poświęcenia własnego życia byłaby nieważna, to jednak nie może ona również zakazywać ofiary z własnego życia, celem ratowania innych. Każdy zatem ma prawo umrzeć za drugiego, nie łamiąc w ten sposób umowy. Paradoksalnie też, właśnie na gruncie metafizycznego egoizmu, ofiara okazuje się prawdziwym heroizmem.

4.1. Męczeństwo. Za jedną z postaci ofiary należy uznać śmierć męczeńską, poniesioną w obronie przekonań religijnych. Początkowo Hobbes traktował ją jako ważny wyjątek od powszechnego dążenia do zachowania własnego życia, później jednak ten pogląd zmodyfikował ${ }^{61}$, pisząc nawet, że nie wszyscy, którzy ponieśli śmierć z racji religijnych, byli męczennikami. Mę-

\footnotetext{
59 Tamże.

${ }^{60}$ Pogląd taki miał głosić starożytny filozof Karneades, dowodząc, że w każdej sytuacji człowiek powinien ratować przede wszystkim siebie, nawet za cenę wyrzucenia innego za burtę statku. Tamże, s. 10.

${ }^{61}$ Tamże, s. 71.
} 
czennik bowiem to świadek, może nim zatem być jedynie bezpośredni uczeń Jezusa; każda inna osoba to jedynie świadek świadka, któremu uczeń Jezusa przekazał własną wiarę w Zbawiciela. Ewentualny obowiązek męczeńskiej śmierci mógłby zatem mieć jedynie bezpośredni uczeń Jezusa ${ }^{62}$.

Hobbes sądził też, że nie warto umierać w imię religii. Można wprawdzie podziwiać tych, którzy nawet pod groźbą śmierci nie ulegli presji porzucenia swej wiary, to jednak nie należy potępiać tych którzy - ratując życie - wyparli się jej, przyjmując nową; jeśli bowiem był to jedynie uczynek zewnętrzny, nie popełnili bałwochwalstwa ${ }^{63}$. Bóg zresztą nie oczekuje od nas heroizmu ani słownych deklaracji; interesuje Go jedynie wiara wyznana sercem.

4.2. Wojna. Z problemem ofiary wiąże się także kwestia wojny jako zbrojnego konfliktu między państwami. Problem jest złożony, rodząc wiele pytań, dotyczących chociażby wszczęcia wojny, która - zawieszając działanie prawa - oznacza powrót do stanu natury. Kłopotliwe jest także utrzymywanie armii, ponieważ żołnierze są zarówno potencjalnymi ofiarami konfliktu zbrojnego, jak i zabójcami. Istotne jest wreszcie pytanie, czy suweren ma prawo żądać od obywateli poświęcenia na wypadek wojny i w jakich okolicznościach wolno mu podjąć decyzję o wojnie.

Zdaniem Hobbesa każda wojna jest złem, którego należy unikać64. Z tego powodu naczelnym obowiązkiem suwerena jest dążenie do pokoju, został bowiem powołany po to, by chronić życie obywateli - tak przed zagrożeniem wewnętrznym, jak i zewnętrznym; sugeruje to, że nie powinien inicjować konfliktu zbrojnego $\mathrm{z}$ innym państwem. $\mathrm{Z}$ drugiej jednak strony to właśnie suweren powinien rozstrzygać, co leży w interesie państwa - wojna czy pokój ${ }^{65}$; opinia obywateli nie ma w tym względzie znaczenia. Optymalne byłoby zawarcie pokoju z wszystkimi państwami, czyli swoista umowa na poziomie międzynarodowym; dopóki jednak nie została zawarta, między państwami istnieje stan natury. W tej sytuacji najbardziej racjonalne wydają się działania zaczepne, celem unieszkodliwienia ewentualnych agresorów.

Skoro zaś uzasadniona jest wojna prewencyjna, to tym bardziej należy usprawiedliwić wojnę obronną; w sytuacji agresji zewnętrznej państwo musi

${ }^{62}$ Szerzej o męczeństwie pisałem w artykule traktującym o eschatologii Hobbesa, złożonym do druku w czasopiśmie „Analiza i Egzystencja”.

${ }^{63}$ T. Hobbes, Lewiatan, s. 737. Zdaniem Hobbesa zresztą w treści religii chrześcijańskiej nie istnieje nic, co mogłoby podważyć lojalność jej wyznawcy wobec suwerena. D. M. Jesseph, Hobbes's Atheism, „Midwest Studies in Philosophy” 26 (2002), s. 162.

${ }^{64}$ T. Hobbes, Lewiatan, s. 663.

${ }^{65}$ R. Tuck, Hobbes, s. 78. 
bowiem podjąć działania zbrojne. Problemem jest jednak, czy suweren ma prawo zmusić obywateli do walki. Na pierwszy rzut oka wydaje się, że nie; skoro bowiem państwo istnieje wyłącznie dla obrony naszego egoistycznego interesu, to obowiązek obrony państwa spada jedynie na suwerena i utrzymywaną przez niego armię. Z perspektywy obywatela bardziej racjonalna wydaje się ucieczka $\mathrm{z}$ kraju, celem przeczekania wojny ${ }^{66}$. Wbrew temu jednak Hobbes uważał, że każdy ma obowiązek bronić ojczyzny - zarówno z racji posłuszeństwa wobec suwerena, jak i własnego interesu, upadek państwa bowiem stanowi dla wszystkich obywateli bezpośrednie zagrożenie ${ }^{67}$. Należy też dostrzec, że w czasie wojny zmieniają się wzajemne zobowiązania między suwerenem i poddanymi. W czasie pokoju to władca ma obowiązek chronić obywateli, w czasie wojny natomiast, to obywatele są zobowiązani bronić władcy ${ }^{68}$.

W wypadku klęski wojennej pokonani powinni korzystać z wszelkich możliwych środków obrony własnego życia, z oddaniem się w niewolę włącznie ${ }^{69}$. Wprawdzie, poddając się, wiele ryzykują, mogą jednak ufać, że zwycięzca ich nie zabije ${ }^{70}$ bądź przynajmniej, że nie zabije od razu; dobrem jest zaś nie tylko uniknięcie śmierci, lecz także jej opóźnienie ${ }^{71}$. Każdy jednak, kto dostanie się do niewoli, jest, według Hobbesa, zwolniony z wszelkich zobowiązańn ${ }^{72}$; ma zatem prawo użyć dowolnych środków obrony życia.

Niezależnie od kwestii działań zbrojnych problemem jest samo utrzymywanie armii; skoro bowiem państwo ma chronić obywateli, to nie powinno

${ }^{66}$ S. Avineri, Hegla teoria nowoczesnego państwa, przeł. T. Rosiński, Warszawa 2009, s. 169.

${ }^{67}$ R. Tuck, Hobbes, s. 78; Y. Abosch, The Conscientious Sovereign: Public and Private Rule in Thomas Hobbes's Early Discourses, "American Journal of Political Science" 50 (2006) 3, s. 632. Dodatkową racją poświęcenia dla ojczyzny jest szlachetność charakteru; w zakończeniu Lewiatana wszak Hobbes złożył hołd swojemu przyjacielowi Sidneyowi Godolphinowi, który doskonale łączył interes prywatny i obowiązek publiczny, lęk przed prawem i odwagę na wojnie. T. Hobbes, Lewiatan, s. 786.

${ }^{68}$ „Do praw natury, jakie ustaliłem [...] chciałbym jeszcze dodać to, że każdy człowiek jest obowiązany z natury rzeczy, o ile tylko leży w jego mocy, ochraniać w wojnie władzę, która go samego ochrania w czasie pokoju". Tamże [podkr. - T. H.].

${ }^{69}$ Tamże, s. 789.

${ }^{70}$ M. Kuniński, Problem stanu natury i stanu politycznego w teorii umowy społecznej Thomasa Hobbesa, [w:] Z. Rau, M. Chmieliński (red.), Umowa społeczna i jej krytycy w myśli politycznej i prawnej, Warszawa 2010, s. 123.

${ }^{71}$ T. Hobbes, Lewiatan, s. 387.

${ }^{72}$ Tamże. 
nikogo uczyć zabijać ani zmuszać do narażania własnego życia ${ }^{73}$. Obowiązku służby wojskowej nie tłumaczy także przywiązanie do rodziny, na wojnie bowiem nie bronię ani siebie ani bliskich ${ }^{74}$. Wbrew tym sugestiom jednak Hobbes gwarantował suwerenowi prawo do powoływania obywateli do armii. Wprawdzie żołnierz jest narażony na śmierć, jednak większym ryzykiem byłby brak wojska, wydając państwo na łup wroga; utrzymywanie armii zatem nie tyle prowadzi do wojny, ile jej groźbę ogranicza. Poza tym każdemu żołnierzowi z osobna utrata życia grozi jedynie potencjalnie, nawet bowiem podjęcie działań wojennych nie oznacza jeszcze skazania na śmierć. W takim jednak razie, zarówno utrzymywanie armii jak i działania zbrojne, podjęte w obronie własnego państwa, są spójne z prawem do życia (a niekiedy są nawet sposobem jego egzekwowania). Znaczy to, że w niektórych sytuacjach człowiek powinien podjąć działania dla dobra wspólnego, nawet, jeżeli mogłyby one grozić mu śmiercią.

5. Władca jako przedmiot prawa. Do tej pory rozważaliśmy prawo z perspektywy interesów obywateli, sugerując - zgodnie z niektórymi sformułowaniami Hobbesa - że władca jest ponad umową. Należy jednak również rozważyć pytanie, czy i w jakim sensie suweren podlega prawu, które sam ustanawia.

Suweren ma nad poddanymi władzę absolutną, oddali mu oni bowiem część swej wolności, zobowiązując się do przestrzegania narzuconego im prawa. Mogłoby to sugerować, że władca ma jedynie uprawnienia, obywatele zaś obowiązki; w rzeczywistości jednak sprawa jest bardziej skomplikowana, już choćby stąd, że trzeba odróżnić osobę władcy od jego funkcji ${ }^{75}$. Zdaniem Hobbesa władza to nie człowiek, lecz wspólna opinia (umowa), której wszyscy się podporządkowują. Suweren jest zatem jedynie reprezentantem wspólnoty, stojącym na straży jej interesów i tylko z tego powodu jest osobą najważniejszą w państwie ${ }^{76}$.

\footnotetext{
${ }^{73}$ S. Avineri, Hegla teoria nowoczesnego państwa, s. 169.

74 Tamże.

75 A. P. Martinich, Hobbes, s. 108-110.

${ }^{76}$ R. Tuck, Hobbes, s. 76, 82. Trzeba też pamiętać, że Hobbes był wyczulony na emocjonalne znaczenie słów, za pomocą których wyrażamy naszą postawę wobec władcy; istnieje wszak różnica między „tyranią" a "monarchią". Chociaż oba słowa oznaczają absolutnego władcę, to jednak wskazują na inne aspekty emocjonalne; o tyranii mówią ci, którzy władcy nie akceptują. A. P. Martinich, Hobbes, s. 189. K. Hoekstra, Tyrannus Rex vs. Leviathan, „Pacific Philosophical Quarterly” 82 (2001), s. 422.
} 
Władca nie znajduje się też ponad umową, lecz jej podmiotem. Jako reprezentant wspólnoty zobowiązuje się on strzec pokoju, gwarantując obywatelom pokój i bezpieczeństwo, obywatele zaś zobowiązują się słuchać rozkazów suwerena, o ile te będą służyć ich interesom. Znaczy to, że władca podlega tym samym prawom, co obywatele ${ }^{77}$, z racji swej roli jednak staje się również za każdego z nich bezpośrednio odpowiedzialny. Paradoksalnie zatem, to władca ma dużo szerszy zakres obowiązków, aniżeli poddani, stając się w gruncie rzeczy ich zakładnikiem. Wprawdzie obywatele zrzekli się części swej wolności, w zamian żądają jednak od suwerena obrony swego życia i interesów. Przyznając suwerenowi szeroki zakres uprawnień w zakresie ustanowienia i egzekucji prawa, poddani nie zobowiązywali się jednak do niesienia mu pomocy w rządzeniu państwem ${ }^{78}$. Sytuacja suwerena jest zatem skomplikowana; z jednej strony zagrożeniem są dla niego wszyscy burzyciele pokoju, z drugiej - jest on zakładnikiem żądań tych, którzy oczekują od niego skutecznej ochrony. Suweren nie ma zatem władzy absolutnej, rządzenie zaś nie jest przywilejem, lecz odpowiedzialną służbą na rzecz dobra wspólnego.

Jak widać, Hobbes nie był zwolennikiem państwa totalitarnego, lecz raczej opiekuńczego, akcentując obowiązki władcy. Jeśli bowiem w państwie znajdują się ludzie, którym brakuje pożywienia, suweren musi im je zapewnić. Zobowiązany jest zatem do takiej redystrybucji dóbr, która zagwarantuje przetrwanie wszystkim ${ }^{79}$. Działania te wynikają nie tyle nawet $\mathrm{z}$ poczucia sprawiedliwości, ile z umowy stojącej na straży pokoju; klęska głodu mogłaby bowiem spowodować niewyobrażalny w skutkach bunt. W interesie wszystkich jest zatem, by nikt nie był nadmiernie ubogi. Władca nie może jednak czekać na charytatywne inicjatywy obywateli, lecz musi skutecznie działać, zapewniając minimum pożywienia wszystkim ${ }^{80}$. W praktyce znaczy to, że musi obciążyć dodatkowymi kosztami ludzi zamożnych po to, by zapewnić

${ }^{77}$ A. P. Martinich, Hobbes, s. 121. Problem równości praw władcy i poddanych jest dosyć skomplikowany. W tekście A Dialogue Between a Philosopher and a Student of the Common Laws of England Hobbes polemizował z tezą Edwarda Coke’a, głoszącą, że król podlega prawu tak samo jak wszyscy obywatele. Zdaniem Hobbesa bowiem władca ma prawo do działań niezgodnych z prawem dla dobra wspólnoty. S. J. Finn, Hobbes, s. 4. Podobny pogląd wyraził w Lewiatanie (s. 352). Sugestia ta może jednak znaczyć, że pozaprawne działania suwerena są dopuszczone nie po to, by obywatelom szkodzić, lecz lepiej służyć ich dobru. Niekiedy zatem łamiąc prawo - władca lepiej spełnia swój obowiązek, niż gdyby literalnie trzymał się jego reguł. Y. Abosch, The Conscientious Sovereign, s. 622.

${ }^{78}$ S. J. Finn, Hobbes, s. 89.

${ }^{79}$ R. Tuck, Hobbes, s. 82.

${ }^{80}$ Tamże. 
konieczne środki do życia ubogim ${ }^{81}$. Rozwijając ten wątek należy powiedzieć, że suweren powinien także zapewnić wszystkim obywatelom pracę i godziwy zarobek, umożliwiający im utrzymanie siebie oraz swoich rodzin. Podobnie konieczne jest zapewnienie wszystkim dostępu do usług medycznych, przynajmniej tych, które bezpośrednio chronią życie; zaniedbywanie służby zdrowia byłoby działaniem na szkodę obywateli, zagrażając ich życiu ${ }^{82}$. Innym obszarem działania władcy powinna być sfera ideologii, w szczególności zakaz głoszenia doktryn burzących pokój; zdaniem Hobbesa zresztą żadna teoria, która prowadzi do wojny, nie może być prawdziwa ${ }^{83}$. Władca ma także obowiązek kontrolowania poddanych, chociaż jedynie w zakresie uczynków zewnętrznych, a nie myśli; w szczególności może zakazać wygłaszania określonych poglądów, chociaż nie ma prawa ani możliwości zakazać wiary w ich słusznośćc ${ }^{84}$. Podobnie jest w przypadku przekonań religijnych; każdy może wyznawać dowolne bóstwa, suweren ma jednak prawo zabronić ich publicznego kultu ${ }^{85}$.

Wymienione zadania władcy wskazują, że musi on dysponować odpowiednią mocą po to, by rządzić sprawiedliwie i skutecznie. Zdaniem Hobbesa jednak największy wpływ na obywateli ma nie prawo i jego egzekwowanie, lecz przykład władcy, który czyni ludzi lepszymi ${ }^{86}$. Z racji swych zadań jednak suweren powinien mieć szczególnie uprawnienia, przede wszystkim w zakresie ochrony życia ${ }^{87}$. Zabójstwo suwerena jest bowiem złem szczególnie niebezpiecznym, mogąc prowadzić do stanu natury; $z$ tego powodu nawet zły władca jest lepszy niż brak jakiegokolwiek władcy. Suweren musi mieć

\footnotetext{
${ }^{81}$ Tamże, s. 82-83. „Suweren interesuje się bogactwem i szczęściem obywateli również dlatego, że siła państwa, będąc sumą mocy obywateli, wzrasta wraz z dobrobytem poddanych". P. Wewiór, Nauka polityczna Thomasa Hobbesa jako technologia władzy, „Studia z Historii Filozofii” 1 (2010), s. 178.

${ }^{82}$ Zapewnienie obywatelom bezpieczeństwa, to nie tylko bezpośrednia troska o zachowanie ich życia, lecz także zapewnienie innych dóbr ułatwiających życie. Y. Abosch, The Conscientious Sovereign, s. 629.

${ }^{83}$ T. Hobbes, Lewiatan, s. 264-265.

${ }^{84}$ Suwerena nie interesuje stan umysłu obywateli ani treść ich wewnętrznych wierzeń, a tylko zewnętrzne uczynki. D. M. Jesseph, Hobbes's Atheism, s. 142.

${ }^{85}$ Prawo bowiem to, zdaniem Hobbesa, „sumienie publiczne”. Y. Abosch, The Conscientious Sovereign, s. 624.

${ }^{86}$ T. Hobbes, Lewiatan, s. 108, 392.

${ }^{87}$ R. Tuck, Hobbes, s. 81.
} 
także gwarancję, że obywatele będą wykonywać jego rozkazy ${ }^{88}$. W interesie poddanych z kolei leży silna władza, słaba bowiem sprzyja agresji i bezprawiu $^{89}$. Nie znaczy to, że obywatele nie mają prawa sprzeciwu wobec władcy; ich bunt jest uzasadniony jednak tylko w sytuacji zagrożenia własnego ży$\mathrm{cia}^{90}$, gdy zatem suweren nie wypełnia skutecznie swoich zadań. „[...] zobowiązanie poddanych w stosunku do suwerena trwa tak długo i nie dłużej, niż trwa moc, dzięki której jest on zdolny ich ochraniac'" ". Zawierając umowę nikt bowiem nie rezygnuje $\mathrm{z}$ prawa do obrony siebie ${ }^{92}$. Znamienne jednak, że Hobbes nie przyznawał obywatelom prawa do buntu przeciwko władzy wybranej nielegalnie, zmieniając zarazem pojęcie legalności władzy; nie odnosi się ono do sposobu jej ustanowienia, lecz do skutecznego pełnienia jej zadań. Tylko zatem taka władza jest nielegalna, która nie chroni życia swoich poddanych; wtedy usprawiedliwiony jest bunt ${ }^{93}$.

Nawet jeśli jednak uznajemy prawo obywateli do sprzeciwu wobec władzy, nie jest oczywiste, że wolno suwerena pozbawić życia. Na pierwszy rzut oka jest to bowiem zło największe, prowadzi bowiem do stanu natury, stanowiącego zagrożenie dla wszystkich ${ }^{94}$. Również skazanie suwerena na śmierć

${ }^{88}$ W skrajnym przypadku nawet rozkaz zabicia innej osoby. A. P. Martinich, Hobbes, s. 122124. W takim przypadku musi jednak istnieć rzeczywiste zagrożenie ze strony tego, którego władca każe zgładzić; gdyby bowiem był to jedynie kaprys suwerena, poddany miałby obowiązek odmówić wykonania rozkazu.

${ }^{89}$ M. Kuniński, Problem stanu natury i stanu politycznego $w$ teorii umowy społecznej Thomasa Hobbesa, s. 118.

${ }^{90}$ J. Rawls, Wykłady z historii filozofii polityki, s. 156.

${ }^{91}$ T. Hobbes, Lewiatan, s. 308.

${ }^{92},[\ldots]$ zawsze mamy uprawnienie do stawienia oporu suwerenowi w samoobronie i do zrobienia tego, co uznajemy za niezbędne do zachowania własnego życia”. J. Rawls, Wykłady z historii filozofii polityki, s. 116.

${ }^{93}$ A. P. Martinich, Hobbes, s. 2, 16. Podobnie Locke dopuszczał możliwość buntu przeciwko władzy, która nie realizuje swoich zobowiązań względem obywateli. S. J. Finn, Hobbes, s. 81. Dodatkowym źródłem prawa do buntu jest fakt, że obywatele nie są przez Hobbesa traktowani jako ślepi wykonawcy poleceń władcy, lecz jako racjonalne istoty, które akceptują narzucone im prawo dlatego, że sami rozpoznają racje dla jego ustanowienia. J. Waldron, Hobbes and the Principle of Publicity, s. 447-474. Absolutyzm Hobbesa można zatem określić mianem absolutyzmu racjonalnego, a reguły prawa uznać za reguły roztropności, pozwalające nam na realizację własnych interesów. S. D. Courtland, A Prima Facie Defense of Hobbesian Absolutism, „Pacific Philosophical Quarterly” 90 (2009), s. 439.

${ }^{94}$ Nawet tyran wydaje się lepszy niż wojna domowa, dopóki bowiem istnieje władza, istnieje prawo i możliwość jego egzekwowania; kiedy zaś władza zostaje obalona, wracamy do stanu natury. Y. Abosch, The Conscientious Sovereign, s. 621, 630. 
przez sąd nigdy nie może być uznane za akt legalny ${ }^{95}$; znaczy to, że należy raczej dążyć do obalenia złego władcy i zastąpienia go innym, niż do zabicia go. Hobbes dopuszczał jednak zgładzenie okrutnego tyrana, jeśli jest to jedyny możliwy sposób przywrócenia bezpieczeństwa obywatelom; w takim przypadku zabity zostaje jednak nie władca chroniący poddanych, lecz okrutnik, który nadużył swej władzy ${ }^{96}$. Świadczy to jednak, że suweren jest nie tylko autorem prawa, lecz także jego podmiotem oraz przedmiotem, tak samo, jak każdy z jego poddanych.

6. Wnioski. Stanowisko Hobbesa w kwestii relacji prawa do śmierci wydaje się zasadniczo spójne i trafne. $Z$ jednej strony słusznie wskazuje on na lęk przed śmiercią jako główne źródło prawa, z drugiej formułuje minimalne zasady, chroniące ludzkie życie. Wprawdzie nikt z nas nie ma obowiązku ratować innych za cenę utraty własnego życia, to jednak nikt również nie ma prawa kogokolwiek zabić. Zasada ta obowiązuje również dzisiaj w wielu systemach prawnych, które nakładają na ludzi obowiązek udzielenia pomocy innym, nie zmuszają jednak nikogo do heroizmu ani ryzykowania własnego życia. Widząc tonącego powinienem wezwać pomoc, jeśli jednak nie umiem pływać, nie mam obowiązku skoczyć do wody.

Zasadniczo trafne jest także w teorii Hobbesa określenie zadań władzy. O ile bowiem obowiązki poszczególnych jednostek są minimalistyczne (nie zabić), o tyle zadania państwa są maksymalistyczne; nie ograniczają się one do niezabijania obywateli, lecz oznaczają konieczność prawnej ochrony wszystkich, świadczenia usług medycznych oraz dostarczania pożywienia. Nie znaczy to, że państwo nie ma prawa stosować wobec obywateli surowych kar, z karą śmierci włącznie. Jeśli bowiem nie ma innych środków przeciwdziałania łamaniu umowy, to kara śmierci okazuje się konieczna; jej zalegalizowanie nie przeczy jednak prawu do życia, zawsze bowiem jest możliwe, że nigdy nie zaistnieje konieczność jej wykonania.

Stanowisko Hobbesa można określić mianem indywidualizmu (czy nawet egoizmu) etycznego, który nie zezwala na żadną formę instrumentalizacji ludzkiego życia. Wartość każdej jednostki jest absolutna, co wyklucza możliwość poświęcenia jej dla dobra innych; Hobbes nie podziela zatem założeń utylitaryzmu. Z perspektywy strategii działań społecznych może się to wydać

\footnotetext{
95 T. Hobbes, Lewiatan, s. 264, 427.

${ }^{96}$ Trzeba też pamiętać, że reguła prawa natury jest zawsze regułą nadrzędną, nawet nad arbitralnymi rozkazami władcy. Y. Abosch, The Conscientious Sovereign, s. 628.
} 
utopijne, z perspektywy jednak wartości i praw przysługujących jednostce wydaje się rozwiązaniem słusznym.

Nie ulega wątpliwości, że egoizm okazuje się istotnie ograniczony, prowadzi bowiem z konieczności do społecznej umowy, najskuteczniej gwarantującej możliwość zachowania życia przez wszystkich. W zakresie obowiązków jednak egoizm ma konsekwencje negatywne, istnieją bowiem sytuacje, w których człowiek powinien raczej bronić życia innych osób niż własnego. Hobbes takiego obowiązku nikomu z ludzi nie przypisywał, należy jednak zauważyć, że właśnie z perspektywy egoizmu można najpełniej docenić ofiarę dla innych. Ofiara jest także konieczna dla dobra wspólnego, skoro bowiem państwo okazuje się gwarancją bezpieczeństwa obywateli, to w sytuacji, gdy samo jest zagrożone, obywatele mają obowiązek bronić go; broniąc państwa nie bronią jednak abstrakcyjnej idei, lecz własnego interesu.

\section{Abstract}

Death as a Source and an Object of Law. Thomas Hobbes' Standpoint (Part II: Death as an Object of Law)

Keywords: Hobbes, history of modern philosophy, death, law, power, capital punishment, suicide, life sacrifice

Thomas Hobbes' standpoint concerning the right for death seems to be coherent as well as justifiable. On one hand he points at the fear of death as the main source of law, but on the other hand he formulates minimum basic rules which safeguard man's life. Though nobody is obliged to rescue someone else at the cost of their own life, but at the same time nobody has a right to kill anyone. Also nowadays the same rule can be found in many legal systems: even if people are obliged to help others, they are not compelled to undertake heroic deeds or risk their lives.

Thus Hobbes' position can be given the name of ethical individualism, or even egoism in which no form of instrumentalism of human life is allowed. The value of any individual is absolute, which excludes the possibility to sacrifice their life for the sake of others. Hobbes does not share assumptions of utilitarianism and his solution might seem utopian from the perspective of the strategy of social actions, but from the perspective of values and rights of an individual it seems justifiable. 